\title{
The Effect of Shocks on the Current and Future Behavior of Sudan Economy: Autoregressive Moving-average Approach
}

\author{
Ahmed Elsheikh M. Ahmed, Associate Professor \\ Department of Econometrics and Social Statistics, \\ Faculty of Economic and Social Studies, Khartoum University, Sudan \\ Leena Ahmed Elsheikh, Lecturer \\ Garden City University, Khartoum, Sudan
}

Doi:10.19044/esj.2020.v16n19p475 URL:http://dx.doi.org/10.19044/esj.2020.v16n19p475

\begin{abstract}
This paper attempts to achieve two core objectives. Firstly, it aims to synthesize the information contained in the different expenditure components of GDP for developing a set of Autoregressive Moving-Average (ARMA) models to examine the effect of shocks on the current and subsequent cyclical deviations of Sudan real GDP from what is trending. Secondly, it aims to compare the intensity of those cyclical deviations within the reviewed period (1970-2010) and outside it. ARMA models of different orders are experimented to distinguish, empirically, whether the effect of shocks is transient or permanent and lasts for a long period of time. The major result is that the lingering effect of shocks is permanent causing intensified deviation from the trend outside the reviewed period.
\end{abstract}

Keywords: Business cycle, ARMA Processes, Permanent shocks, Transient shocks, Difference stationary, Trend stationary

\section{Introduction}

Coherent studies document the nature, sources, causes, and transmission mechanisms of recurrent economic fluctuations for developing economies. Although growing, they are still inadequate compared with voluminous literature for advanced economies according to the study of Kyland and Prescott (1982). Agner et al. (2000) claimed that developing economies tend to be inclined to abrupt crises, shocks, and distinct gyrations in macroeconomic variables. This makes it difficult to discern any kind of cycle. In this current study, two specific aspects were addressed. The first aspect is to ascertain whether the effect of shocks on Sudan real GDP path is permanent and lasts for a long period of time or is transient and fades away 
over time. The second aspect is to measure cycles of Sudan real GDP as deviations from a linear trend and to examine their intensity within the reviewed period (1970-2010) and outside it, specifically the period 20112018. The starting year 2011 marked the secession of South Sudan with an event that caused a turbulent shock to the whole pattern of Sudan economy. The deviations from trend are obtained both as cyclical residuals and as cyclical relatives.

A noticeable feature of Sudan economy over the period 1970-2010, beside others, is the persistent rise in the long-term growth rate of the real GDP despite the violent short -term fluctuations caused by multitude of shocks, both adverse and benevolent. These shocks are further exacerbated by other problems, namely: allocation inefficiencies, a poorly developed infrastructure, and inadequate attitudinal and institutional structures. The looming problem, however, facing Sudan economy is how it will react to the future effect of those shocks. Does the future path of real GDP remain closer to a linear trend or it will sway far away from it? This depends on the ability of policymakers and decision takers in identifying the driving forces that lie behind the prospective deviations from trend and in the effectiveness of the policy actions that must be taken to mitigate them.

Sudan economy has experienced different kinds of shocks which affected its performance over the reviewed period $(1970-2010)$. Some of these shocks have positive productive effect while others have negative debilitating effect. The nature of the emerged net effect on the behavior of real GDP depends on the strength and direction of these conflicting shocks effect. This means that whether these shocks have positive or negative effect on the current and future path of Sudan, real GDP will eventually be determined by the most forceful and dominant. On the other hand, whether the net effect on the current and future path of real GDP is purely random and is dying out quickly over time or stays for good depends on the nature of the stochastic process underlying the behavior of the real GDP.

Business cycle studies have adopted different classifications for shocks. In this study, a rather broad classification for the sources of shock is adopted. Thus, the shock has economic or noneconomic origin. The sources of economic shocks, in turn, can be categorized into two main groups: internal and external. The internal adverse shocks arise primarily from bad, faulty domestic economic policies and ill-conceived economic plans. For instance, in the case of Sudan: nationalization, confiscation or forced liquidation, extra budgetary expenditure practices, and the failure of the economic plan initiated in 1971 intended to encourage export promotion and import substitution, but it ended up in further current account deficits, etc. The external economic shocks, adverse or benevolent, are originated from international economic policies and events. For example, in the 1980s the interest rates soared to 
higher levels in the more developed world due to the adoption of antiinflationary policies. On the other hand, the noneconomic shocks can also be classified into two main components: man-made shocks such as civil wars and non-man-made shocks such as natural hazards.

These shocks precipitate either negative or positive effects on the economic activity as pointed out earlier irrespective of where they belong in the classification used. Hence, the emphasis is laid on the sources of shocks and their destabilizing effect rather than where they belong in the classification. They can be summarized, broadly, as follows in the case of Sudan economy:

- One important source of shock is related to the domain of fiscal and monetary policies. The striking feature of the behavior of the central government expenditure, over the reviewed period, reveals somewhat persistent budget deficit implying expansionary fiscal policy. The increase in expenditure is partly attributable to some development projects particularly during the peace time period but mainly to defense and security expenditure absorbing almost two-thirds of the total current expenditure in recent years. This was primarily due to the intensity of civil war in South Sudan which followed the collapse of Addis Ababa Peace Agreement in 1983 and the military conflicts in Darfur, South Kordfan, and the Blue Nile region more recently.

Furthermore, in the context of monetary policy, there was a persistent monetary expansion, as measured by the annual growth rate of money supply and net domestic assets over the reviewed period. Towards the end of this period, specifically the last three years, 2008, 2009 and 2010, the annual growth rates of money supply were $10.2 \%, 23.5 \%$, and $25.4 \%$ respectively. With regard to the exchange rate, despite the fact that it remained fixed up to 1978 , it began to deteriorate ever since due to the implementation of the devaluation policy recommended by the IMF. The devaluation policy was continued during 1980 s and 1990s to serve two purposes: to stabilize the economy and to bridge the trade balance gap. However, it failed in both counts. It resulted in persistent current deficit and, hence, contributed to more economic instability.

- One of the early debilitating shocks, which had lingered effect for quite some time, occurred at the beginning of the reviewed period, specifically May 1970 when the then regime nationalized all commercial banks and confiscated many private industrial enterprises. Most of the nationalized undertakings ran at a loss due to sheer mismanagement which proved to be commercially unviable. Eventually, the government was forced to subsidize these losses out of 
its annual budget. This was one flagrant example of a faulty public policy which contributed to the persistence of the budget deficit.

- Changes in investor's optimism. Despite some favorable concessions offered by the latest Sudan Investment Act, the investment environment is still not encouraging to induce optimism attributable to macroeconomic instability, public policy uncertainty, and arbitrary regulations particularly the period which preceded the discovery of oil in 1999. All this contributed in creating hostile investment environment.

- Negligence and lack of maintenance led to deteriorated capital stocks and damaged most agricultural schemes. The most important of all is Gezira scheme besides some other infrastructural projects.

- One source of shock, which led to chronic difficulties, is the accumulation of external debt over time. Sudan external debt grew from 5.163 million US dollars in 1980 to 37.8 million US dollars in 2010. Interests (penalty and arrears) constitute substantial proportion of it. Many factors, both internal and external, are responsible for such remarkable increases in external debt. The internal factors are the expansionary fiscal policy which led to extra budgetary expenditure as pointed out above. This is in addition to the expansionary monetary policy. The external factors involve the oil shocks of the 1970s and 1980s and the high foreign interest rates. All those factors, internal and external, contributed in overvaluing of the Sudanese pound creating balance of payments problem, hence, inducing more external borrowing. In view of the strong relationship between the stock of external debt and growth, the persistent increases in external debt precipitates detrimental effects on the growth rate of Sudan real GDP. Moreover, the external debt service, exacerbated by the accumulation of penalty interest, crowded out private investment and changes the composition of public expenditure. It also played a significant role in increasing the government budget deficit and in reducing public savings. All this led to retarded economic growth in some years. The relationship between external debt and economic growth was investigated empirically for developing countries by a number of studies, e.g., Catherine et al. (2002), Ajay and Oke (2012), Choong et al. (2010), Malik et al. (2010), and Gebrail (2020).

- There are other sources of shock which originate from international economic disturbances. For instance, a sudden increase in foreign interest rates may have immediate influence on the foreign exchange rate and domestic investment. This, in turn, may affect the net exports [trade balance] which represent the current account of the balance of payments. To be more specific, the current account of Sudan economy 
is in deficit over the entire reviewed period with exception of the year 1972. Sudan receives aids and borrows in world financial markets. In fact, it is a net borrower, importing more goods than exporting. However, while private capital inflows to developing countries are booming, the share of Sudan has been insignificant attributable to poor infrastructure, inefficient labor force, and implementation of excessive restrictive government policies. To access capital from world financial markets, Sudan needs to upgrade its infrastructure and create conducive environment for investment.

- Another source of shock pertains to currency speculation. Abrupt change in foreign exchange speculators confidence in the currency impacts the behavior of the foreign exchange rate. In Sudan, the major participants are authorized dealers, namely: commercial banks, foreign exchange bureaus, public and private sectors. Those entities are under the control and/or supervision of the central bank. However, the challenging problem is the unauthorized or illegal currency traders in the Black Market. Their baseless irrational speculations and malpractices play a significant role in the volatility of the exchange rate in most part of the reviewed period. They discouraged exports and this led to import-reliance. Furthermore, there were changes in net export, and the inflow of capital had been contributing to more volatility in the exchange rate. The presence of multiple exchange rates also endangered Sudan's external competitiveness and created a host of domestic problems as stated by Elbadawi (1994), Suliman (2000), Gerling (2012), Arabi (2012), and Abdalla (2016).

- Civil wars stifling the country for the past forty years. Displacement of civil population due to the civil wars adversely affects the distribution of labor force. On the other hand, the internal migration led to the urban Giantism problem caused mainly by concentration of economic activities and social services in few large cities, e.g., Khartoum city in Sudan created the so-called first city bias, which attracted most of the public and private investments compromising rural development. Policies that encourage urban decentralization should be pursued.

- Corruption plays a significant role in destabilizing Sudan economy. Corruption practices are mainly confined to the public sector as evidenced by the annual reports of Sudan General Auditor. It usually takes the form of embezzlement, sub rosa payment, and nepotism. Furthermore, according to the 2012-2018 Corruption Perception Index, Sudan is one of the 20 bottom countries that were ranked as having the highest perceived levels of corruption. 
- The designation of Sudan as state Sponsor of Terrorism in August, 12, 1993, by the USA government. Inclusion in the list imposes strict unilateral sanctions. In 1997, further economic sanctions were imposed by the USA. This external shock wreaked havoc on the stability of Sudan economy over the 1990s and up to this moment.

- Political instability: internal political infightings among political parties and other aspirants for power, e.g., ethnic blocs vying for power. The whole political system is paralyzed due to power struggle, and it needs urgent reform. However, such political reform must be initiated by grassroots mobilization and supplemented by a Constitution that limits executive power through a series of checks and balances.

- Migration of professionals and skilled personnel, for political and economic reasons, all over the world led to serious brain drain creating severe shortage in highly qualified and well trained labor force. However, it should be noticed that the remittances of those migrants is one source of the country's foreign exchange, which is counted as a significant factor for long-term growth of the aggregate economy (Ebaidalla \& Edriess, 2013).

- The recent increases in world grain prices, particularly wheat, is used as a raw material for producing different products in Sudan, and the most important of all is bread. This external shock led to severe shortages of the imported wheat flour. The government was forced to change its policy targeting the accessibility and affordability of this strategic commodity to the public. However, the new policy was unsuccessful. Domestic prices of bread were inflated. The weight of the loaf was diminished. Eventually, bread became highly inaccessible. Customers had to wait in long queues for hours to access just little loaves. This development sparked the recent political uprising in Sudan which led eventually to the change of the defunct regime. It is one of the shocks which occurred outside the reviewed period but could have repercussions on the future behavior of the economy.

- The most disastrous shock, not only involving Sudan economy but the entire world, is the tripled oil price which rose back in 1973. In a similar manner, oil prices increased in three consecutive years (1979, 1980 and 1981) respectively by the following percentages: $25.4,47.8$, and 44.7. However in 1986, oil prices fell by nearly half (-44.5\%), which can be considered as a positive shock (Hamilton, 1983).

- One shock which could have both positive and negative effects on Sudan economic performance is the discovery and exporting of oil in 
August 1999. This attracted impressive foreign direct investment. Sudan jumped from $62^{\text {nd }}$ in 2000 to the $18^{\text {th }}$ in 2004 on the UNCTAD Inward Foreign Direct Investment Performance Index. Oil and its byproducts became the most essential Sudanese exports and basic source supporting the government budget. It also contributed to the development of other sectors, thus, boosting potential output. However, the almost exclusive dependence on oil exports during the last decade of the reviewed period had created a host of problems, namely: greater export concentration undermining long term diversification and increase in the likelihood presence of the notorious Dutch Disease symptoms. In comparison with the Nigerian economy, see Ibrahim et al. (2014).

- Wild cutting of forest trees for use as wood and charcoal for household cooking and boiling of water contributes to the exacerbation of desertification and deforestation and leads to more environmental degradation. Moreover, poor ventilation in the house increases indoor air pollution caused by smoke from burning firewood. In general, such use of biomass fuel, partially in the periphery of urban centers and mostly in rural areas, precipitated detrimental impacts on health and quality of life. Hence, it contributed partially in reducing labor productivity and potential output. Government initiatives - targeting environmental conservation by reducing pressure on dwindling forest resources - are urgently needed.

The non man-made shocks, as a category on their own, are mainly caused by adverse environmental conditions. Also, because of their sporadic nature, their effect on the aggregate economic activity can easily be traced. They can be enumerated separately as follows:

- Drought and desertification plaguing Sudan since the early eighties, in its more ecologically sensitive areas, led to internal migration. This is besides the civil wars as pointed out earlier. This has detrimental impact on traditional production and, ultimately, this endangered food security in rural areas and led to the well-publicized famine of 19841985. The effects of drought and desertification were not confined to Sudan; they also engulfed neighboring countries forcing massive influxes into Sudan. Their effect must be recognized and due allowance should be made for their outcome.

- Heavy rains and floods in different rainy seasons which led to disastrous effects on most rain promoted agricultural schemes. They could be held responsible for the reduced total exports of the agricultural products for some years. 


\section{Materials and Methods}

To explore the effects of shocks, as highlighted above in the introduction, on the stability of Sudan economy over the reviewed period, a VAR model is specified by decomposing Sudan real GDP into its four components namely: personal consumption expenditure (pc), investment expenditure (iv), government expenditure (gx), and trade balance (tb). On the other hand, operational ARMA models are formulated to reflect the nature of its dynamic process to help discern whether the effect of shocks on the current and future cyclical deviations of real GDP from its trend are purely random and fades away quickly over time or have permanent nature. For more detailed analysis, the behavior of the real GDP is assumed to follow an upward linear trend with added stochastic component $\left(\mu_{t}\right)$ as specified in equation (1) below. An elaborate justification for why a linear characterization, in particular, is used for specifying the trend will be given in the developments that will come. On the other hand, stochastic component has been added to represent the random shocks emanating from all kinds of sources. An implicit assumption underlying the specification of the ARMA models is the flexibility of prices. The plausible rationalization of this assumption is that a long period of time extending from 1970 to 2010 was used to specify, estimate, and evaluate the models. Hence, prices cannot be sticky over this extended span of time. As a consequence, such an assumption is needed to incorporate the dynamic adjustment process underlying Sudan economy. Moreover, in a developing economy, such as Sudan economy, one cannot expect that the level of nominal output to be fixed will fluctuate either with changes in prices or physical output or both. For more informative analysis, the effect of price changing over time is netted out to allow the use of the actual quantities of the GDP. Consequently, the nature of fluctuations in the actual physical output cannot be attributed to change in the price levels. In light of those assumptions, an essential component of the ARMA model is specified as follows:

$$
\begin{gathered}
\text { GDP }=a_{0}+a_{1} t+\mu_{t} \ldots . \\
\text { Where, } \quad \mu_{t}=b \mu_{t-1}+\varepsilon_{t}
\end{gathered}
$$

$\varepsilon_{\mathrm{t}}$ is a white noise series, $\mathrm{b}$ is less than one, and $\mu_{t}$ denotes the deviations from trend. Hence, equation (2) represents an ARMA $(1,0)$ process.

By simple algebraic manipulation, equations (1) and (2) can be combined to give equation (3) below. The emerged lagged dependent variable on the right hand side of this equation can be viewed as a variable representing the dynamic evolution of real GDP over time. One central result of this study is based on the estimated value of the coefficient of this lagged variable as the two assumed cases below indicate.

$$
\mathrm{GDP}_{\mathrm{t}}=\left[\mathrm{a}_{0}(1-\mathrm{b})+\mathrm{ba}_{1}\right]+\mathrm{a}_{1}(1-\mathrm{b}) \mathrm{t}+\mathrm{bGDP} \mathrm{t}-1+\varepsilon_{\mathrm{t}}
$$


The two cases concern the magnitude of the lagged dependent variable, namely: whether the coefficient of the lagged dependent variable $b$ in equation (3) is less than one $(b<1)$ or equal to one $(b=1)$, i.e., containing a unit root.

Case I: A trend stationary process where $\mathrm{b}$ is less than one, $(\mathrm{b}<1)$.

At the outset, it is important to find out whether the original values of Sudan real GDP series are stationary or not, hence, an Augmented DickeyFuller test is used for this purpose.

If the non-stationarity of the real GDP series is established, transforming the series to induce stationarity could lead to either trend stationary (TS) if the actual values fluctuate around a trend with steady and stable amplitude or alternatively to difference stationary. In either case, the first difference of $\mathrm{GDP}_{t}$ is stationary. To explain more, equation (1) shows that the first difference of real GDP can be written as:

$$
\Delta \mathrm{GDP}_{t}=a_{1}+\Delta \mu_{t}
$$

Where $\Delta \mu_{t}$ is stationary since in the autoregressive component $\mu_{t}=b \mu_{t-1}+$ $\varepsilon_{\mathrm{t}}$, the autocorrelation coefficient $\mathrm{b}$ is assumed to be less than one as pointed out above, $|\mathrm{b}|<1$.

By assumption, $\mu_{t}$ is ARMA $(1,0)$. Hence, one can easily show that $\Delta \mu_{t}$ is $\operatorname{ARMA}(1,1)$.

Case II: A difference stationary (DS) process where $b$ is equal to one, $b=1$. This means that the autoregressive component has a unit root. Presently, in this case, the actual values of the series of $\mathrm{GDP}_{t}$ fluctuate like before but move away from the linear trend. Substituting for $b=1$ in equation (3) gives:

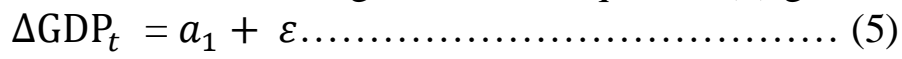

$\Delta \mathrm{GDP}_{t}$ is a sum of constant and white noise series, hence it is stationary.

In appearance, equations (4) and (5) look indistinguishable. In actual fact, they are quite different. In equation (5), $\varepsilon_{t}$ represents the random effect of both the economic and noneconomic shocks. The shocks have a transient diminishing effect on the real $\mathrm{GDP}_{t}$ if the trend stationary (TD) is proved empirically to be the case or otherwise they have permanent effect indicative to the fact that the process is a difference stationary (DS) case.

To make a distinction between the two cases, recall that the autoregressive component in equation (2) measures the deviation of $\mathrm{GDP}_{t}$ from trend in period t. This means that cycles are viewed as deviation from the trend. Trend developments must not be confused with the variation about the trend. The main concern of the study is about deviation from the trend. Hence, to explore the effect of shocks on the current and subsequent deviations 
of Sudan real GDP from a linear trend whether they are permanent or transient, a lag operator (L) is used to rewrite equation (2) as follows:

$$
\mathrm{A}(\mathrm{L}) \mu_{t}=\varepsilon_{t}
$$

Where

A $(\mathrm{L})=1-b L \quad$ denotes a first order polynomial in $\mathrm{L}$. The reciprocal or inverse of $\mathrm{A}(\mathrm{L})$ can be written as a limit to infinite geometric progress:

$A^{-1}(\mathrm{~L})=\frac{1}{1-b L}=1+\mathrm{bL}+b^{2} L^{2}+b^{3} L^{3}+\ldots \ldots$.

Accordingly, equation (6) can be written as:

$$
\mu_{t}=\varepsilon_{t}+\mathrm{b} \varepsilon_{t-1}+b^{2} \varepsilon_{t-2}+
$$

Successive partial derivatives over time give:

$$
\frac{\partial \mu_{t+s}}{\partial \varepsilon_{t}}=b^{s}, \mathrm{~s}=1,2,3 \ldots, \infty
$$

The magnitude of $b$ is decisive in differentiating whether the ARMA process is trend stationary or difference stationary. If the value of $b$ is lying between -1 and +1 , the process is trend stationary (TSP) and the effect of shocks die out. On the other hand, if the value of $b$ is equal to one, $b=1$, the process is difference stationary (DSP) and the effect of shocks lasts a long time. Hence, the distinction between the two cases is essentially an empirical issue. It is discussed at length in the following section.

\section{Results and Discussions}

Table 1 below, which contains the results of the VAR model, reveals that four of the roots modules lay outside the unit circle. It indicates that the different expenditure components of the real GDP do not satisfy the stability condition. 
Table 1. VAR Results

\begin{tabular}{|c|c|}
\hline $\begin{array}{l}\text { Roots of Characteristic } \\
\text { Endogenous variables: } \\
\text { Exogenous variables: } \\
\text { Lag specification: } 12 \\
\text { Date: } 10 / 17 / 19 \text { Time: }\end{array}$ & $\begin{array}{l}\text { iial } \\
\text { C IV GX TB }\end{array}$ \\
\hline Root & Modulus \\
\hline $\begin{array}{l}1.255999-0.096247 \mathrm{i} \\
1.255999+0.096247 \mathrm{i} \\
0.206598-1.192405 \mathrm{i} \\
0.206598+1.192405 \mathrm{i} \\
0.914992 \\
-0.793456 \\
0.007407-0.777289 \mathrm{i} \\
0.007407+0.777289 \mathrm{i} \\
-0.366946 \\
-0.108621\end{array}$ & $\begin{array}{l}1.259681 \\
1.259681 \\
1.210171 \\
1.210171 \\
0.914992 \\
0.793456 \\
0.777325 \\
0.777325 \\
0.366946 \\
0.108621\end{array}$ \\
\hline
\end{tabular}

Source: compiled by authors

The instability is accentuated by the results of the Augmented Dickey Fuller test as presented in Table 2 below.

Table 2. Augmented Dickey-Fuller Test

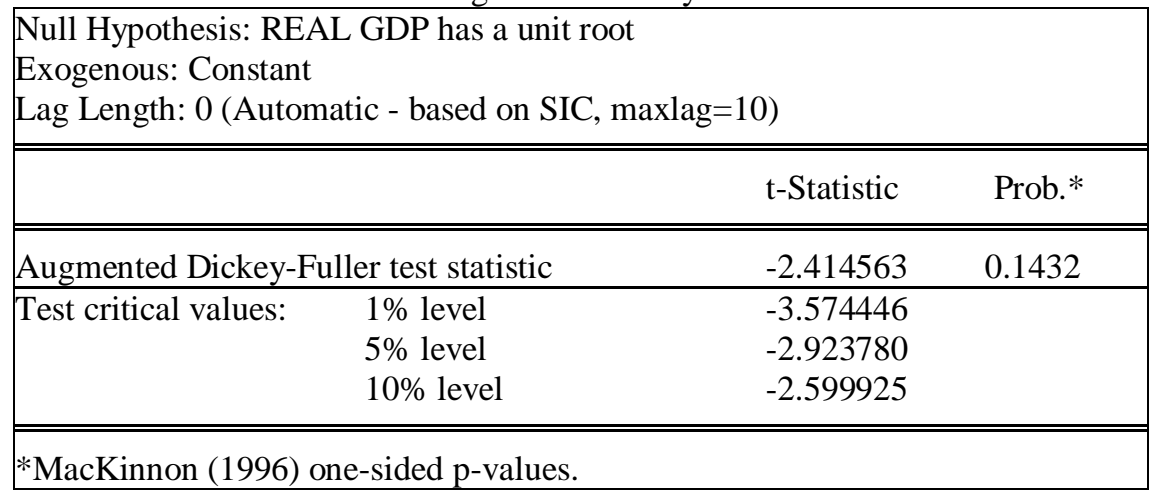

Source: compiled by authors

Presently, the focus is on a simple stochastic structure for the disturbance term in equation (1) as it is described by an ARMA $(1,0)$ process. However, for a comprehensive perspective, the ARMA process can be extended to higher orders to ascertain if there is a change in the magnitude of the coefficient of the lagged dependent variable $b$. The autoregressive component of $\mathrm{GNP}_{\mathrm{t}}$ in equation (2) can be written as:

$$
\text { A (L) } \mu_{\mathrm{t}}=\mathrm{B}(\mathrm{L}) \varepsilon_{\mathrm{t}}
$$


Where, A (L) and B (L) are polynomials of order $\mathrm{p}$ and q respectively. If A (L) contains a unit root, the result is a difference stationary series (DS), and the first difference of the $\mathrm{GDP}_{t}$ can be modeled as $\operatorname{ARMA}(\mathrm{p}-1, \mathrm{q})$.

To obtain more reliable empirical results for the first order and other higher orders to discern between the above two cases outlined above, the sample period is made to end in 2010 due to the secession of South Sudan in June 2011. The period beyond 2010 also destabilized the estimated parameters attributable to structural break caused by this adverse event. The structural break is evidenced by Chow Break Point test as seen in Table 3 below.

Table 3. Chow Breakpoint Test

\begin{tabular}{|cccc|}
\hline \multicolumn{4}{|c|}{$\begin{array}{c}\text { Chow Breakpoint Test: } 2011 \\
\text { Null Hypothesis: No breaks at specified breakpoints }\end{array}$} \\
& Equation Sample: 1970 2017 & \\
\hline \hline & 62.13678 & Prob. F(5,38) & 0.0000 \\
$\begin{array}{c}\text { F-statistic } \\
\text { Log likelihood } \\
\text { ratio } \\
\text { Wald Statistic }\end{array}$ & 106.4070 & Prob. Chi-Square(5) & 0.0000 \\
\hline \hline
\end{tabular}

Source: compiled by authors

All models are estimated by using E-Views package. Based on the estimated coefficient of the lagged dependent variable $\mathrm{GDP}_{t-1}$ in equation (3) for the simple process ARMA $(1,0)$, or other higher order processes, one can tell by the emerged estimated magnitude whether the process represents a trend or difference stationary model.

As can be seen from Tables 4, 5, 6, 7, and 8 presented below for ARMA processes of different orders, the coefficient of the lagged dependent variable for the different models experimented with are equal to one (rounded to one decimal place), and they are statistically significant judging by the zero p-value. Moreover, the overall fit of the ARMA models, judging by the adjusted $R^{2}$, is quite adequate. All this gives a clear guide line for the choice of case II. Accordingly, the deviations of the real GDP from a linear trend line are not purely random. They are durative which continue to last for a long time. Consequently, this affects the long-term behavior of Sudan real GDP as a growth indicator. 
Table 4. Results of the ARMA $(1,0)$

\begin{tabular}{|c|c|c|c|c|}
\hline \multicolumn{5}{|c|}{$\begin{array}{l}\text { Dependent Variable: GDP } \\
\text { Method: ARMA Maximum Likelihood (OPG - BHHH) } \\
\text { Date: 04/13/19 Time: 04:20 } \\
\text { Sample: } 1971 \text { 2010 } \\
\text { Included observations: } 40 \\
\text { Convergence achieved after } 6 \text { iterations } \\
\text { Coefficient covariance computed using outer product of gradients }\end{array}$} \\
\hline Variable & Coefficient & Std. Error & $\mathrm{t}$-Statistic & Prob. \\
\hline $\begin{array}{c}\mathrm{C} \\
\mathrm{T} \\
\text { GDP(-1) } \\
\text { AR(1) } \\
\text { SIGMASQ }\end{array}$ & $\begin{array}{c}-7.087698 \\
0.308676 \\
1.057544 \\
0.102965 \\
137.2779\end{array}$ & $\begin{array}{l}5.910181 \\
0.398616 \\
0.074498 \\
0.210660 \\
33.39614\end{array}$ & $\begin{array}{c}-1.199235 \\
0.774369 \\
14.19554 \\
0.488776 \\
4.110592\end{array}$ & $\begin{array}{l}0.2385 \\
0.4439 \\
0.0000 \\
0.6280 \\
0.0002\end{array}$ \\
\hline $\begin{array}{l}\text { R-squared } \\
\text { Adjusted R-squared } \\
\text { S.E. of regression } \\
\text { Sum squared resid } \\
\text { Log likelihood } \\
\text { F-statistic } \\
\text { Prob(F-statistic) }\end{array}$ & $\begin{array}{c}0.955959 \\
0.950925 \\
12.52554 \\
5491.117 \\
-155.2030 \\
189.9271 \\
0.000000\end{array}$ & \multicolumn{2}{|c|}{$\begin{array}{l}\text { Mean dependent var } \\
\text { S.D. dependent var } \\
\text { Akaike info criterion } \\
\text { Schwarz criterion } \\
\text { Hannan-Quinn criter. } \\
\text { Durbin-Watson stat }\end{array}$} & $\begin{array}{l}112.0450 \\
56.54158 \\
8.010151 \\
8.221261 \\
8.086482 \\
1.991844\end{array}$ \\
\hline Inverted AR Roots & \multicolumn{3}{|c|}{.10} & \\
\hline
\end{tabular}

Source: compiled by authors

Table 5. Results of the ARMA $(1,1)$

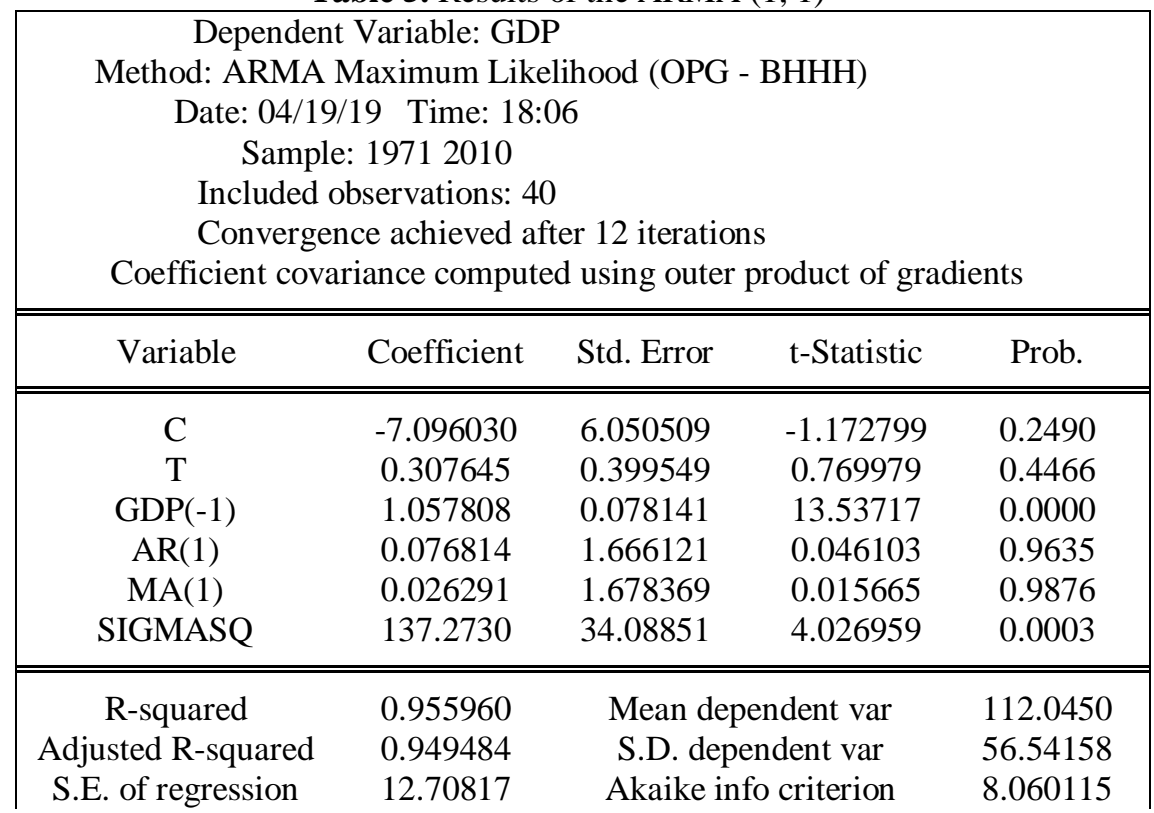




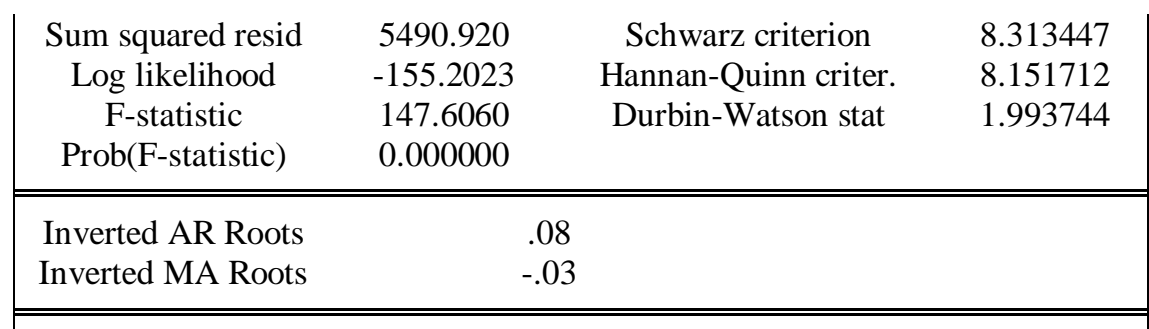

Source: compiled by authors

Table 6. Results of the ARMA $(2,1)$

\begin{tabular}{|c|c|c|c|c|}
\hline \multicolumn{5}{|c|}{$\begin{array}{l}\text { Dependent Variable: GDP } \\
\text { Method: ARMA Maximum Likelihood (OPG - BHHH) } \\
\text { Date: 04/13/19 Time: 04:38 } \\
\text { Sample: } 19712010 \\
\text { Included observations: } 40 \\
\text { Convergence achieved after } 15 \text { iterations } \\
\text { Coefficient covariance computed using outer product of gradients }\end{array}$} \\
\hline Variable & Coefficient & Std. Error & $\mathrm{t}$-Statistic & Prob. \\
\hline $\begin{array}{c}\mathrm{C} \\
\mathrm{T} \\
\text { GDP(-1) } \\
\text { AR(2) } \\
\text { MA(1) } \\
\text { SIGMASQ }\end{array}$ & $\begin{array}{c}-7.045400 \\
0.313452 \\
1.056260 \\
0.020313 \\
0.105106 \\
137.2654\end{array}$ & $\begin{array}{l}6.136028 \\
0.405585 \\
0.079023 \\
0.171984 \\
0.213225 \\
34.00707\end{array}$ & $\begin{array}{c}-1.148202 \\
0.772840 \\
13.36652 \\
0.118110 \\
0.492934 \\
4.036378\end{array}$ & $\begin{array}{l}0.2589 \\
0.4450 \\
0.0000 \\
0.9067 \\
0.6252 \\
0.0003\end{array}$ \\
\hline $\begin{array}{l}\text { R-squared } \\
\text { Adjusted R-squared } \\
\text { S.E. of regression } \\
\text { Sum squared resid } \\
\text { Log likelihood } \\
\quad \text { F-statistic } \\
\text { Prob(F-statistic) }\end{array}$ & $\begin{array}{c}0.955963 \\
0.949487 \\
12.70782 \\
5490.616 \\
-155.2016 \\
147.6146 \\
0.000000\end{array}$ & \multicolumn{2}{|c|}{$\begin{array}{l}\text { Mean dependent var } \\
\text { S.D. dependent var } \\
\text { Akaike info criterion } \\
\text { Schwarz criterion } \\
\text { Hannan-Quinn criter. } \\
\text { Durbin-Watson stat }\end{array}$} & $\begin{array}{l}112.0450 \\
56.54158 \\
8.060081 \\
8.313412 \\
8.151677 \\
1.989825\end{array}$ \\
\hline $\begin{array}{l}\text { Inverted AR Roots } \\
\text { Inverted MA Roots }\end{array}$ & .14 & & & \\
\hline
\end{tabular}

Source: compiled by authors 
Table 7. Results of the ARMA $(1,2)$

\begin{tabular}{|c|c|c|c|c|}
\hline \multicolumn{5}{|c|}{$\begin{array}{l}\text { Dependent Variable: GDP } \\
\text { Method: ARMA Maximum Likelihood (OPG - BHHH) } \\
\text { Date: 04/19/19 Time: 17:50 } \\
\text { Sample: } 1971 \text { 2010 } \\
\text { Included observations: } 40 \\
\text { Convergence achieved after } 16 \text { iterations } \\
\text { Coefficient covariance computed using outer product of gradients }\end{array}$} \\
\hline Variable & Coefficient & Std. Error & $\mathrm{t}-$ Statistic & Prob. \\
\hline $\begin{array}{l}\mathrm{C} \\
\mathrm{T} \\
\text { GDP(-1) } \\
\text { AR(1) } \\
\text { MA(2) } \\
\text { SIGMASQ }\end{array}$ & $\begin{array}{l}-7.025039 \\
0.315726 \\
1.055644 \\
0.106332 \\
0.013546 \\
137.2573\end{array}$ & $\begin{array}{l}6.162051 \\
0.407187 \\
0.079121 \\
0.213153 \\
0.169704 \\
34.01404\end{array}$ & $\begin{array}{r}-1.140049 \\
0.775382 \\
13.34218 \\
0.498851 \\
0.079821 \\
4.035313\end{array}$ & $\begin{array}{l}0.2622 \\
0.4435 \\
0.0000 \\
0.6211 \\
0.9368 \\
0.0003\end{array}$ \\
\hline $\begin{array}{c}\text { R-squared } \\
\text { Adjusted R-squared } \\
\text { S.E. of regression } \\
\text { Sum squared resid } \\
\text { Log likelihood } \\
\text { F-statistic } \\
\text { Prob(F-statistic) }\end{array}$ & $\begin{array}{c}0.955965 \\
0.949490 \\
12.70745 \\
5490.292 \\
-155.2007 \\
147.6237 \\
0.000000\end{array}$ & \multicolumn{2}{|c|}{$\begin{array}{l}\text { Mean dependent var } \\
\text { S.D. dependent var } \\
\text { Akaike info criterion } \\
\text { Schwarz criterion } \\
\text { Hannan-Quinn criter. } \\
\text { Durbin-Watson stat }\end{array}$} & $\begin{array}{l}112.0450 \\
56.54158 \\
8.060035 \\
8.313367 \\
8.151632 \\
1.989343\end{array}$ \\
\hline $\begin{array}{l}\text { Inverted AR Roots } \\
\text { Inverted MA Roots }\end{array}$ & \multicolumn{3}{|c|}{.11 } & \\
\hline
\end{tabular}

Source: compiled by authors

Table 8. Results of the ARMA $(2,2)$

\begin{tabular}{|c|c|c|c|c|}
\hline \multicolumn{5}{|c|}{$\begin{array}{l}\text { Dependent Variable: GDP } \\
\text { Method: ARMA Maximum Likelihood (OPG - BHHH) } \\
\text { Date: 04/19/19 Time: } 17: 57 \\
\text { Sample: } 19712010 \\
\text { Included observations: } 40 \\
\text { Failure to improve objective (non-zero gradients) after } 40 \text { iterations } \\
\text { Coefficient covariance computed using outer product of gradients }\end{array}$} \\
\hline Variable & Coefficient & Std. Error & $\mathrm{t}$-Statistic & Prob. \\
\hline $\begin{array}{l}\mathrm{C} \\
\mathrm{T} \\
\operatorname{GDP}(-1) \\
\mathrm{AR}(2) \\
\mathrm{MA}(2) \\
\text { SIGMASQ }\end{array}$ & $\begin{array}{r}-7.551028 \\
0.272685 \\
1.069890 \\
-0.758535 \\
0.999999 \\
120.4815\end{array}$ & $\begin{array}{l}5.599968 \\
0.343351 \\
0.070863 \\
0.286275 \\
823.5849 \\
49821.47\end{array}$ & $\begin{array}{r}-1.348405 \\
0.794188 \\
15.09804 \\
-2.649674 \\
0.001214 \\
0.002418\end{array}$ & $\begin{array}{l}0.1864 \\
0.4326 \\
0.0000 \\
0.0121 \\
0.9990 \\
0.9981\end{array}$ \\
\hline R-squared & 0.961347 & Mean d & dent var & 112.0450 \\
\hline
\end{tabular}




\begin{tabular}{|cccc|} 
Adjusted R-squared & 0.955663 & S.D. dependent var & 56.54158 \\
S.E. of regression & 11.90558 & Akaike info criterion & 7.995410 \\
Sum squared resid & 4819.259 & Schwarz criterion & 8.248742 \\
Log likelihood & -153.9082 & Hannan-Quinn criter. & 8.087007 \\
F-statistic & 169.1256 & Durbin-Watson stat & 1.812660 \\
Prob(F-statistic) & 0.000000 & & \\
\hline \hline Inverted AR Roots & $-.00+.87 \mathrm{i}$ & $-.00-.87 \mathrm{i}$ & \\
Inverted MA Roots & $-.00+1.00 \mathrm{i}$ & $-.00-1.00 \mathrm{i}$ & \\
\hline \hline
\end{tabular}

Source: compiled by authors

The different kinds of shocks that affect the dynamic behavior of Sudan economy are summarized in the introduction section. As can be seen, some of the shocks are adverse while others are benevolent. Accordingly, it is rather difficult to tell precisely whether the net effect of all these shocks is positive, indicative to uptrend, or negative, indicative to downtrend. This is due to the fact that a number of macroeconomic variables are implicitly involved in the measurement of the real GDP series and their responses to the different shocks may have contradictory nature. Furthermore, attributable to the interactive nature of these variables, it is not possible to measure neither the magnitude nor the direction of the net effect of shocks in a direct reliable manner. This is exacerbated by the sporadic occurrences of those shocks. In addition, the intrinsic interest is not on whether the trend is deterministic or stochastic or they coexist in the real GDP realization over the reviewed period, but on whether the specification of a linear trend in particular is justifiable (Motaff \& Akpan, 2017). Hence, to justify and back up the assumption that the trend is linear, as shown in equation (1) above, one can invoke the fact that changes in the amounts of real GDP year after year are usually very slow and proceed in a gradual manner without sudden or unexpected changes in direction. Thus, straight line can describe adequately the average behavior within the reviewed period. However, from a theoretical standpoint, one should not exclude the possibility that the rate of change of the real GDP may vary from period to period. A second justification is that the use of nonlinear trend equation may increase the possibility of generating explosive behavior for the values of the real GDP rendering them economically irrelevant. Hence, to obtain the cyclical deviations from a linear trend, projecting from straight line that covers the recent period (2011-2018) is a more logical choice. On the other hand, to justify why it is trending upward, in particular, this can be resolved empirically by fitting a linear trend over the reviewed period (19702010).

Towards this end, the Least Squares method is used to estimate equation (1) by taking the year 1970 as the origin for specifying the values of the time variable t. The results are presented in Table 9 below. As the table 
reveals, the estimated equation is: $\mathrm{GDP}=77.02+0.86 \mathrm{t}$. The value of the slope parameter is positive. One may observe that the coefficient of $t$ is statistically insignificant and the adjusted $R^{2}$ is quite low, but this is justifiable by the fact that time is the only variable used to explain the real GDP. For this purpose, the interest is only centered on the direction of the trend. Hence, the positive sign of the slope answers the question why an upward linear trend is assumed in equation (1) over the reviewed period. This same estimated equation is used to obtain the cyclical deviations of the real GDP from the trend as explained below.

Table 9. Results of the Least Squares Method

\begin{tabular}{|c|c|c|c|c|}
\hline \multicolumn{5}{|c|}{$\begin{array}{c}\text { Dependent Variable: REALGDP } \\
\text { Method: Least Squares } \\
\text { Date: 10/13/19 Time: 09:43 } \\
\text { Sample: } 1970 \text { 2018 } \\
\text { Included observations: } 49\end{array}$} \\
\hline Variable & Coefficient & Std. Error & $\mathrm{t}$-Statistic & Prob. \\
\hline $\mathrm{C}$ & 77.02242 & 16.87499 & 4.564296 & 0.0000 \\
\hline $\mathrm{T}$ & 0.858654 & 0.587512 & 1.461510 & 0.1505 \\
\hline R-squared & 0.043471 & \multirow{7}{*}{\multicolumn{2}{|c|}{$\begin{array}{l}\text { Mean dependent var } \\
\text { S.D. dependent var } \\
\text { Akaike info criterion } \\
\text { Schwarz criterion } \\
\text { Hannan-Quinn criter. } \\
\text { Durbin-Watson stat }\end{array}$}} & 98.48878 \\
\hline Adjusted R-squared & 0.023120 & & & 58.84490 \\
\hline S.E. of regression & 58.16068 & & & 11.00426 \\
\hline Sum squared resid & 158985.2 & & & 11.08147 \\
\hline Log likelihood & -267.6043 & & & 11.03355 \\
\hline F-statistic & 2.136012 & & & 0.490431 \\
\hline Prob(F-statistic) & 0.150530 & & & \\
\hline
\end{tabular}

Source: compiled by authors

Sudan real GDP is measured on annual basis. This facilitates the process of isolating cycles as the annual data consists only of two major components, namely: the trend and the cycle. There are no seasonal variations. On the other hand, the random movements exert negligible influences upon annual data. The trend can be viewed as the statistical norm and the typical value which represents the normal annual growth. Consequently, the cyclical fluctuations are derived as deviations from these normal or typical values known as the trend. Empirically, they are the difference between the original values and the estimated values of GDP. The estimated values are obtained from the estimated equation GDP $=77.02+0.86 \mathrm{t}$, given above. In symbols, this difference is denoted as $\{\mathrm{GDP}-\widehat{G D P}\}$. It is called cyclical residuals based on the additive time series model. On the other hand, to obtain the cyclical relatives, one can simply divide the original values of the real GDP by its estimated values using the multiplicative time series model. 
To compare the intensity of the deviations from the trend within the reviewed period (1970-2010) and the period 2011-2018, four means are obtained by using the absolute values of the cyclical residuals and the cyclical relatives for both periods as shown in Table 10 below:

Table 10. Mean absolute cyclical residuals and relatives

\begin{tabular}{|l|l|l|}
\hline $\begin{array}{l}\text { Period } \\
\text { Type of Measure }\end{array}$ & $1970-2010$ & $2011-2018$ \\
\hline Mean absolute cyclical residuals & 39.3 & 59.3 \\
\hline Mean absolute cyclical relatives & 44.6 & 62.8 \\
\hline
\end{tabular}

Source: computed by the authors

The information contained in the table reveals clearly that both the means of the absolute cyclical residuals and absolute cyclical relatives are far smaller in the period 1970-2010 compared with the period 2011-2018. This indicates that the intensity of the deviations from the trend is far greater outside the reviewed period due the persistent effects of shocks on the future behavior of Sudan real GDP. This is confirmed by the underlying mechanism of Sudan real GDP as it follows a difference stationary process (DSP). The situation is even more aggravated when one adds to those shocks the ones that occurred beyond the reviewed period. The most severe of all is the secession of South Sudan.

\section{Conclusion}

Based on the obtained results it seems that Sudan economy is subject to looming threats in the future attributable to the rather persistent deviations from the uptrend caused by various kinds of shocks. Moreover, the future is uncertain and highly unpredictable in a country such as Sudan which is characterized by both economic and political instability and lack of reliable information. The information and database needed to assist in taking quick decisions is rather weak due to lack of financing and understaffing of data collection agencies. Sometimes the required information is either difficult to access or not readily available in order to make informed or fact-based policy decisions to mitigate the effect of shocks which contribute in straying away the path of real GDP from its trend. Furthermore, the occurrences of abrupt unfavorable domestic and international events aggravate the situation even more.

The adverse shocks, in particular, have a complex nature which makes it rather difficult to disentangle their separate effects on the fundamental macroeconomic variables. For instance, the external shocks that affect financial resources take many forms such as adverse terms of trade, increased interest rate for foreign loans, meager inflow of foreign capital, etc. These external shocks play central role in adversely impacting the internal and external balances of the economy, in particular, its supply side. Hence, this plays a part in slowing the growth rate of output. 
Furthermore, other types of noneconomic shocks associated with psychological factors (inertia) which interact with the existing fluctuations in the major components of aggregate demand evoke even more reduction in the growth rate of real output. The lingering of these adverse types of shocks encouraged commodity brokers and currency arbitrageurs to the dollarization of the domestic currency. The malpractice is pervasive and has deleterious effects on the whole economy. It provides compelling insights into the functioning of the economy that led some economic analysts to offer a grimmer judgment undermining the credibility of those who are responsible for the management of the economy. They argue that there is a credibility gap between what they advocate and what they practice.

To mitigate the future adverse effects of the different kinds of pernicious shocks as highlighted above, focused economic reform agenda is required. The most urgent required reforms can be summarized as follows:

- In the context of fiscal policy, revision of the taxing system is imperative. A tax structure with high flexibility and revenuegenerating capability should be highly advocated, i.e., with marginal rate greater than average rate needed for a realization of reasonable surplus to meet the ever-increasing demand for the expansion of current and development government expenditures. It is high time for the government to shift its emphasis from indirect taxes, which accentuates poverty, to direct taxes which are commonly known by their high income elasticity, equitability, and built-in flexibility.

- Structural reform for the whole of the financial sector, in particular, the prevailing regularity laws and procedures, related to many different forms of fees and charges, impedes the internal trade and the production process as a whole. In addition, the removal of government imposed restrictions on financial intermediaries is required to ensure fair credit opportunities not influenced by affirmed political allegiance and to assist in establishing a more market-based system of monetary management. Sudan banking system is weak and undercapitalized. Therefore, it should be strengthened by pursuance of the right policies. On the other hand, one basic characteristic of Sudan economy is its cash nature. Bank customers prefer quick access to their deposits, and others mostly in rural areas keep cash under their pillows. The bank can use these lower saving deposits to extend loans. Diligent efforts are needed to promote financial inclusion in order to make financial services accessible to a large proportion of the population and businesses to boost savings and investments. Moreover, financial integration with other neighboring countries is important (Nzioka, 2017). 
- Reduction of government budget deficits to avoid financing by borrowing from the banking system and seigniorage.

- Financial control over all revenue generated by the activities of the different government units should strictly be observed. This is because a significant proportion of it is siphoned out escaping proper channeling and ending up outside the auspices of the Ministry of Finance. Power without control and countervailing forces is extremely damaging.

- Commitment to the itemized expenditure of the budget to prevent extra budgetary spending.

- Curb of custom exemptions to some influential individuals and institutions. Creation of institutions resistant to political manipulation is of utmost significance.

- Crack down on rampant corruption: embezzlement and other financial irregularities plaguing the public sector is evidenced by the annual reports of Sudan General Auditor. These revealing reports and other international indices of transparency rarely prompt legal actions. They are customarily neglected by the government. Such negligence and lack of accountability, as the "Broken Windows Theory of Criminology" suggests, is invitation to more serious crimes. Even though it is not an acceptable justification, some corruption practices are induced by lower wages and salaries. Hence, this necessitates complete revision of the public sector pay structure and the government should be more responsive to the pay-claim. Thus, a committee was formed by the existing interim government to revise the public pay structure but its recommendations are not yet declared.

- Debt management used to be an extricable problem before the establishment of the External Debt Unit in the Central Bank of Sudan back in 2000. Before this year, there was complete lack of coordination between institutions responsible for debt management. This Unit should be strengthened in order to execute specific functions in a proper manner, namely: debt documentation, supervision, and followup (Gebrail, 2020).

- In connection with technology shocks, upgrading of infrastructure and rehabilitation of the existing neglected agricultural schemes, e.g., Gezira scheme and others are urgently needed. Both replacement and new investment should be encouraged to redress technical regress that led to the slow economic growth rate, which was felt heavily in remote marginalized rural areas. Such improved infrastructure creates favorable environment for investment, hence supporting inclusive economic growth (Ali \& Elbadawi, 2002; Bannage, 2002). 
- Revision of the privatization policy adopted since 1992 is urgently needed. One of its damaging repercussions is overpriced retail goods compared with the purchasing power of the current salaries and wages. In addition, prices of most goods and services had risen inexorably. Retail markets, in particular, become entirely undisciplined. This is a problem derived from the illegal act and malpractice of some immoral middlemen who engulf the whole of the goods market. Moreover, the erratic behavior of unauthorized currency dealers and speculators due to the unpredictability of Sudanese foreign exchange black market has exacerbated the volatility of the exchange rates. As a consequence, government interference to curb such practices and to regulate these unfettered distorted markets is a necessity under such circumstances. It should be viewed as a key disciplinary tool to render morality to these markets rather than undesirable government interference in a free market functioning. Public policy is ultimately about what is best for the people.

The different kinds of adverse supply shocks, as pointed out above, reduce incomes. Hence, this reduces the flow of private savings into financial markets. Consequently, adoption of economic policies encouraging national saving, both public and private, to fund new and replacement investments in order to expand the productive capacity of the economy are of imperative significance. Such policies assist much in closing the finance gap. Policymakers should attempt to reduce sources of risk to raise investment by boosting the optimistic mood and confidence of investors.

- Sudan suffers from a severe balance of payments deficit for a long period of time which originated mostly from unfavorable terms of trade, declining demands for imports in the developed countries, and erratic domestic foreign trade policies. The lack of fund to finance the deficit needs urgent structural adjustment programs to improve the balance of payments which, in turn, assists in absorbing the external and internal shocks.

Stabilization of the economy requires massive efforts and overzealous pursuit of effective economic policy package by paying close attention to set priorities that strives to minimize the effects of these economic and noneconomic shocks on the future path of Sudan economy. A new perspective and a new vision with defined scope are urgently needed to secure smooth functioning of the Sudan economy in the future.

\section{References:}


1. Abdalla, S.Z. (2016). "Modeling the Sources and Impact of Macroeconomic Fluctuations in Sudan", Institute of Developing Economies, Japan Trade Organization, V.R.F. Series No.495.

2. Agenor, P.R., Dermort, C.J., \& Prasad, E.S. (2000). "Macroeconomic Fluctuations in Developing Countries : Some Stylized Facts," The World Bank Economic Review,14(2).

3. Ajayi \& Oke (2012). "Effect of External Debt on Economic Growth and Development of Nigeria" International Journal of Business and Social Science, Vol. 3 No.12.

4. Ali, A. \& Elbadawi, I. (2002). "Explaining Sudan's Growth Performance", AERC collaborative Research Project on Explaining Africa's Growth Performance.

5. Arabi, K. (2012). Estimation of Exchange Rate Volatility Via GARCH Model: Case Study OF Sudan” International Journal of Economic and Finance.

6. Bannage, A. (2002). "The Impact of the Structural Adjustment Policies on Economic Growth in Sudan" DSA Conference, University of Greenwich, London.

7. Barrow, R.J. (1981). "Output Effect of Government Purchases", Journal of Policies. Economy, 89.

8. Catherine et al. (2002). "External Debt and Growth", Working Paper No.69, International Monetary Fund (IMF).

9. Choong et al. (2010). "Does Debts Foster Economic Growth? The Experience OF Malaysia”, African Journal Business Management, Vol. 4(8).

10. Ebaidalla, M. \& Edriess, A. (2012). "The Flow of Migrant's Remittances into Sudan: The Role of Macroeconomic Environment." Paper Prepared for the Economic Research Forum $18^{\text {th }}$ Annual Conference on Corruption and Economic Development, Cairo, Egypt, 25-27 March.

11. Elbadawi, I. (1994). The Expatriate Worker's Remittances, Parallel Foreign Exchange.

12. Gebrail, M. (2020). "The Impact of External Debt on Economic Growth: An Empirical Assessment of Sudan 1970-2010”. Unpublished Ph.D. Thesis, Graduate College, Khartoum University, Sudan.

13. Gerling, K. (2012). “Assessing Sudan's External Competitiveness", International Monetary Fund, Selected Issues, (IMF Country Report) 12/299.

14. Hamilton, J.D. (1983). "Oil and the Macro economy since World War 2", Journal of Political Economy,91. 
15. Ibrahim, A., Ayodele, A., \& Hakeem, M. (2014). "Oil Price Shocks and Nigerian Economic Growth", European Scientific Journal,Vol.10, No. 19.

16. Moffat, I.U. \& Akpan, E.A. (2017). "Time Series Modeling of the Interaction Between Deterministic and Stochastic Trends", International Journal of Advanced and Applied Sciences, 4(9)

17. Nzioka, O.M. "Investigating the Relationship between Financial integration and economic growth in the East African community." European Scientific Journal, Vol. (13). No 19.

18. Suliman, K.M. (2000). "The Sources of Macroeconomic Fluctuations in Sudan". Unpublished Ph.D. Thesis, Graduate College, Khartoum University, Sudan.

19. Wohlmuth, K. (ed). (1989). "Structural Adjustment in the world economy and East - West - South Economic", Institute for world Economics and international management, university of Bremen. 